ISSN: 2224-0616

Int. J. Agril. Res. Innov. \& Tech. 2 (2): 9-14, December, 2012 Available online at http:// www.ijarit.webs.com

\title{
EFFECTS OF STOCKING DENSITY ON GROWTH AND PRODUCTION PERFORMANCE OF INDIGENOUS STINGING CATFISH, Heteropneustes fossilis (Bloch)
}

\author{
A.H.M. Kohinoor ${ }^{*}$, M.M. Khan ${ }^{2}$, S. Yeasmine ${ }^{3}$, P. Mandol ${ }^{4}$ and M.S. Islam $^{5}$
}

Received 31 May 2012, Revised 13 November 2012, Accepted 25 December 2012, Published online 31 December 2012

\begin{abstract}
An on-farm experiment was undertaken in nine earthen ponds to evaluate the growth and production potentials of stinging catfish shing, Heteropneustes fossilis for the period of six months from March to August 2010. Three stocking densities such as 1,25,000 ( $\left.\mathrm{T}_{1}\right)$, 1,87,500 $\left(\mathrm{T}_{2}\right)$ and 2,50,000 ha-1 $\left(\mathrm{T}_{3}\right)$ were tested with three replications each. Fish were fed with commercial pelleted feed containing 35\% crude protein. After six months rearing, the mean harvesting weights of shing were $69.42 \pm 6.20,58.74 \pm 3.85$ and $49.50 \pm 4.52 \mathrm{~g}$ in $\mathrm{T}_{1}, \mathrm{~T}_{2}$ and $T_{3}$, respectively. Significant $(P<0.05)$ highest mean harvesting weight was found in $T_{1}$. The best survival was found in $\mathrm{T}_{1}(87 \%)$ among the treatments. The calculated mean production of shing ( $\mathrm{H}$. fossilis) in three treatments such as $\mathrm{T}_{1}, \mathrm{~T}_{2}$ and $\mathrm{T}_{3}$ were $7549 \pm 52$, $9031 \pm 71$ and $8786 \pm 60 \mathrm{~kg} \mathrm{ha}^{-1}$, respectively, which were significantly different $(\mathrm{p}<0.05)$ from each other.
\end{abstract}

Keywords: Growth, Stinging Cat fish, Stocking Densities, Earthen Pond

${ }^{1,2,3 \& 5}$ Freshwater Station, Bangladesh Fisheries Research Institute, Mymensingh, Bangladesh

${ }^{4}$ Senior Assistant Chief, Ministry of Fisheries \& Livestock, Bangladesh.

*Corresponding author's email: kohinoor41@ gmail.com (A.H.M. Kohinoor)

\section{Introduction}

Among the air-breathing catfishes, stinging catfish (Heteropneustes fossilis) is very popular and high valued fish in Bangladesh. This fish is locally known as Shingi or Shing. It is considered to be highly nourishing, palatable and tasty and well preferred because of its less spine, less fat and high digestibility in many parts of Indian subcontinent (Khan et al., 2003). The species is very high content of iron $\left(226 \mathrm{mg} 100 \mathrm{~g}^{1}\right)$ and fairly high content of calcium compared to many other freshwater fishes. Due to high nutritive value the fish is recommended in the diet of sick and convalescents. Being a lean fish it is very suitable for people for whom animal fats are undesirable (Rahman et al., 1982). It is a very hardy fish and can survive for quite a few hours outside the water due to presence of accessory respiratory organs. It can tolerate slightly brackish water. The fish adapts well to hypoxic water bodies and to high stocking densities (Dehadrai et al., 1985). This fish was abundantly available in open water system of floodplains, canals, beel and haors of Bangladesh. But due to over exploitation and ecological changes in its natural habitats; this species have become threatened. Indiscriminate destructive practices have caused havoc to aquatic bio-diversity in Bangladesh (Hussain and Mazid, 2001). Presently, H. fossilis is one of the threatened fish in Bangladesh (IUCN Bangladesh, 2000). This fish has enormous aquaculture potential and it could be easily grown in ponds and small ditches. Culture of $\mathrm{H}$. fossilis has yet been well flourished in Bangladesh due to lack of appropriate culture technique. Considering its status of threatened status, high market value and high consumer demand it is essential to develop suitable culture technique. The culture technique will helpful to prevent the fish from being extinct and at the same time this delicious tasty fish will be available for the rural and urban people.

Although the air breathing fish Shing is in high market demand, hither to very little attention has been paid to develop culture techniques. Earlier accounts on this species include seasonal morphology of gonads in relation to the biology (Azadi and Siddique, 1986; Kuddus et al., 1995), induced breeding for fry production (Thakur et al., 1977; Saha, 1998), food and feeding habits (Kuddus et al., 1995) and nutrition (Hossain et al., 1993; Anwar and Jafri, 1995). But few published literature are available on growth and production of $\mathrm{H}$. fossilis in pond, cistern and net cages (Lipton, 1983; Haque et al., 1988; Narejo et al., 2005; and Khan et al., 2003). Considering the lack of information on these lines, the present investigation was carried out to ascertain the optimum stocking density of $\mathrm{H}$. fossilis in pond ecology for sustainable production. 


\section{Materials and Methods}

\section{Pond selection and preparation}

The experiment was conducted for a period of six months from March to August 2010 in nine farmer's ponds of 400-600 $\mathrm{m}^{2}$ area with a depth of $1.0-1.5 \mathrm{~m}$ at Modhupur, Tarakanda, Mymensingh. Prior to stocking, ponds were dried and cleaned for weeds and unwanted aquatic animals. The dried ponds were left exposed to sunlight for several days and then limed at the rate of $250 \mathrm{~kg} \mathrm{ha}^{-1}$. Five days after liming, ponds were filled-up with deep tube well water up to the depth of 1 meter. After three days, ponds were fertilized with cowdung at the rate of $1,000 \mathrm{~kg}$ ha1.

\section{Experimental design}

Three different stocking densities of shing $(\mathrm{H}$. fossilis) were tested in the experiment. Stocking density was maintained as treatment and which replicated thrice. Fingerlings of shing were stocked at the rate of $1,25,000,1,87,500$ and $2,50,000$ ha $^{-1}$ in $\mathrm{T}_{1}, \mathrm{~T}_{2}$ and $\mathrm{T}_{3}$, respectively.

\section{Source of fingerlings}

The fingerlings of $\mathrm{H}$. fossilis were used in this experiment were collected from a private hatchery of Mymensingh, Bangladesh. The sizes of fingerlings were $3.26 \pm 0.55,3.44 \pm 0.46$ and $3.24 \pm 0.39 \mathrm{~g}$ in $\mathrm{T}_{1}, \mathrm{~T}_{2}$ and $\mathrm{T}_{3}$, respectively.

\section{Fish stocking}

Fingerlings of $\mathrm{H}$. fossillis were stocked in 01 March 2010 according to the experimental design. All ponds of various sizes were divided randomly into three treatment groups viz. group1 (T1), group- 2 (T2) and group-3 (T3). The ponds belong to Treatment- $1\left(T_{1}\right)$, Treatment- $2\left(T_{2}\right)$ and Treatment-3 $\left(\mathrm{T}_{3}\right)$ were stocked with $\mathrm{H}$. fossillis fingerlings at the stocking density of $1,25,000$ $\left(T_{1}\right)$, 1,87,500 $\left(T_{2}\right)$ and 2,50,000 ha-1 $\left(T_{3}\right)$, respectively.

\section{Post stocking management}

After stocking, in order to meet up the increasing dietary demand, commercial fish feed named Saudi Bangla Fish feed (starter-2) containing $35 \%$ crude protein were applied as supplementary feed at the rate of $4-10 \%$ of standing biomass of fish twice daily at $0500 \mathrm{hrs}$ and $1900 \mathrm{hrs}$ daily. Proximate composition of the feed was determined following the standard methods given by Association of Official Analytical Chemists (AOAC) (1984) in the Feed and Nutrition Laboratory of Freshwater Station, Bangladesh Fisheries Research institute, Mymensingh. The amount of feed was adjusted fortnightly on the basis of sampling of experimental fish. The proximate composition of the feed is shown in Table 1. Besides this, lime was applied in all the ponds at the rate of $125 \mathrm{~kg}$ ha ${ }^{-1}$ at monthly interval.

Table 1. Proximate analyses of the feed used (\% dry mater basis)

\begin{tabular}{ccccc}
\hline Dry mater & Protein & Lipid & Ash & Crude fiber \\
\hline $81.10 \pm 2.0$ & $35.00 \pm 1.0$ & $3.11 \pm 0.09$ & $18.20 \pm 0.2$ & $10.10 \pm 0.68$ \\
\hline
\end{tabular}

\section{Fish sampling}

Random samples of 50 fish from each pond were sampled fortnightly by using a seine net. The total weight was measured by using a portable balance (Tanita, Japan).

\section{Water sampling and analysis}

Water quality parameters such as water temperature, transparency, $\mathrm{pH}$, dissolved oxygen (DO) and total alkalinity were determined at weekly interval between 0900 to $1000 \mathrm{hrs}$. Temperature was recorded using a Celsius Thermometer, dissolve oxygen and $\mathrm{pH}$ meter (Hanna pH 300) and a portable digital DO meter (MI 605, MARTINI).

\section{Harvesting of fish}

At the end of the experiment, the fishes were harvested, first by seine netting and then by draining out of the ponds. The harvested fishes were counted and weight was recorded to find out the survival rate and production, respectively. Specific growth rate (SGR) was estimated as:

SGR $\left(\% b^{-1} d^{-1}\right)=[$ In (final weight) - In (initial weight)]/culture period (days) $\times 100$

\section{Data analysis}

Data were analysed using the statistical package, Statgraphics Version 7. ANOVA was performed on all the dependent variables to see whether the treatment had any significant effect or not.

\section{Results}

\section{Water quality parameter}

Mean values of physico-chemical parameters over the period of shing farming are presented in Table 2. The water temperature in $\mathrm{T}_{1}, \mathrm{~T}_{2}$ and $\mathrm{T}_{3}$ ranged from: $24.60-30.7^{\circ} \mathrm{C}, 23.88-29.84^{\circ} \mathrm{C}$ and $24.50-30.30^{\circ} \mathrm{C}$, respectively with the mean values $27.90 \pm 1.12,27.86 \pm 1.09$ and $27.49 \pm 1.11$ The mean water temperature in $T_{1}, T_{2}$ and $T_{3}$ 
were not statistically significant $(\mathrm{P}<0.05)$. The water transparency showed significant $(\mathrm{p}<0.05)$ difference among the treatments. The mean values were $24.65 \pm 3.11,26.00 \pm 3.92$ and $2014 \pm 2.40 \mathrm{~cm}$ in $\mathrm{T}_{1}, \mathrm{~T}_{2}$ and $\mathrm{T}_{3}$, respectively. Mean transparency values differed significantly $(\mathrm{P}<0.05)$, increasing from $\mathrm{T}_{3}$ to $\mathrm{T}_{1}$. The level of $\mathrm{pH}$ varied from 7.10-8.20, 7.15-8.70 and 7.08- 8.60 in $\mathrm{T} 1, \mathrm{~T} 2$ and T3, respectively.

The dissolved oxygen content in the experimental ponds ranged from 4.70 to $6.80,4.27$ to 6.70 and 3.31 to 6.90 in $\mathrm{T}_{1}, \mathrm{~T}_{2}$ and $\mathrm{T}_{3}$, respectively, with the mean values $5.32 \pm 0.14,4.79 \pm 0.32$ and $4.23 \pm 0.47$ $\mathrm{mg} \mathrm{L}^{-1}$. Comparatively lower level of dissolved oxygen as observed in the treatment-3. Dissolved oxygen values ( $\mathrm{mg} \mathrm{L}^{-1}$ ) did not differ significantly $(\mathrm{P}<0.05)$. Total alkalinity ranged from 85 to 128 , 87 to 138 and 84 to $140 \mathrm{mg} \mathrm{L}-1$ with mean values of $109 \pm 6.96,113 \pm 9.58$ and $117 \pm 10.29 \mathrm{mg} \mathrm{L}^{-1}$ in $T_{1}, T_{2}$ and $T_{3}$, respectively. These values did not show any significant difference $(\mathrm{P}<0.05)$ among the treatments.

The range of mean values of ammonia-nitrogen (unionized) was $0.033 \pm 0.012,0.042 \pm 0.021$ and $0.055 \pm 0.031$ in $T_{1}, T_{2}$ and $T_{3}$, respectively. The highest ammonia-nitrogen value was 0.97 in the month of August in $\mathrm{T}_{3}$ and the lowest value was 0.017 in the month of March in $T_{1}$. The differences among treatments were significant $(\mathrm{P}>0.05)$ when compared using ANOVA.

Table 2 . Water quality parameter (mean \pm SE) of the ponds under different treatments

\begin{tabular}{llll}
\hline Parameter & Treatment-1 & Treatment- & Treatment-3 \\
\hline Temperature $\left({ }^{\circ} \mathrm{C}\right)$ & $27.90 \pm 1.12$ & $27.86 \pm 1.09$ & $27.49 \pm 1.11$ \\
& $(24.60-30.70)$ & $(23.88-29.84)$ & $(24.50-30.30)$ \\
Transparency $(\mathrm{cm})$ & $24.65 \pm 3.11^{\mathrm{b}}$ & $26.00 \pm 3.92^{\mathrm{b}}$ & $20.14 \pm 2.40 \mathrm{a}$ \\
Dissolved oxygen $(\mathrm{mg} / \mathrm{L})$ & $5.32 \pm 0.14^{\mathrm{a}}$ & $4.79 \pm 0.32^{\mathrm{b}}$ & $4.23 \pm 0.47 \mathrm{~b}$ \\
$\mathrm{pH}$ & $7.10-8.20$ & $7.15-8.70$ & $7.08-8.60$ \\
Total Alkalinity $(\mathrm{mg} / \mathrm{L})$ & $102.00 \pm 6.96$ & $113.00 \pm 9.58$ & $123.00 \pm 10.29$ \\
Total ammonia $(\mathrm{mg} / \mathrm{l})$ & $0.033 \pm 0.012$ & $0.042 \pm 0.021$ & $0.055 \pm 0.031$ \\
\hline
\end{tabular}

Figures in the same row having the same superscripts are not significantly different ( $\mathrm{P}>0.05)$

\section{Growth and production}

Details of stocking, harvesting, growth, FCR, SGR and production of shing (H. fossilis) in the three treatments during the study period are shown in Table 3. Growth of shing in ponds was investigated and the results obtained from the experiment indicated that the growth rate varied in different stocking densities. On the basis of final growth attained at harvest under $\mathrm{T}_{1}, \mathrm{~T}_{2}$ and $\mathrm{T}_{3}$ were $69.42 \pm 6.20,58.74 \pm 3.85$ and $49.50 \pm 4.52$, respectively. The highest harvesting weight was obtained in $\mathrm{T}_{1}$ and lowest in $\mathrm{T}_{3}$. The harvesting mean weight showed significant differences $(\mathrm{P}<0.05)$ in $\mathrm{T}_{1}$ followed by $\mathrm{T}_{2}$ and $\mathrm{T}_{3}$ when ANOVA was performed. The monthly sampling weights of fish under different stocking densities are shown in Fig. 1.

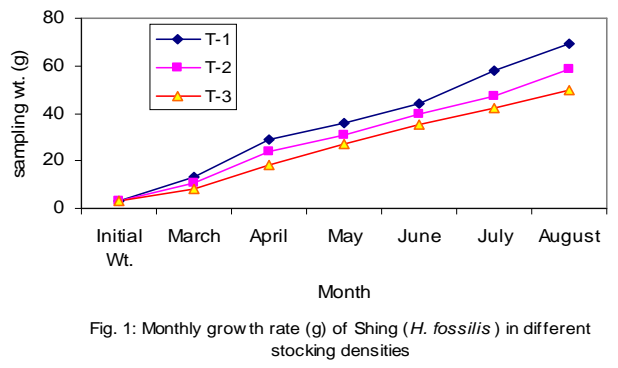

The Figure indicates that the growth rate was always higher in $T_{1}$ then followed by $T_{2}$ and $T_{3}$. The results showed that higher growth rate was observed at against lower stocking densities. The specific growth rate (\% per day) of fish in different treatments varied among the treatments. Highest value was obtained in $\mathrm{T}_{1}$ and lowest in $\mathrm{T}_{3}$. SGR in $\mathrm{T}_{1}$ was significantly higher than $T_{3}$, while $T_{2}$ was not significantly different from $T_{1}$, but was significantly different from $T_{3}$. FCR was significantly lower in $T_{1}$ than in $T_{2}$ and $\mathrm{T}_{3}$. Therefore, SGR and FCR were best for fish in $\mathrm{T}_{1}$ where lowest number of fingerlings was reared $\left(1,25,000\right.$ ha $\left.^{-1}\right)$.

The percentage of survival as recorded in the present study was $87 \pm 3.6,82 \pm 4.58$ and $71 \pm 2.64$ for $T_{1}, T_{2}$ and $T_{3}$, respectively. The highest survival rate was observed in $\mathrm{T}_{1}$ and the lowest in $\mathrm{T}_{3}$. Differences in survival rates among the treatments were found to be significant $(\mathrm{P}<0.05)$. The mean production of shing was 7,549 $\pm 52,9,031 \pm 71$ and $8,786 \pm 60 \mathrm{Kg} \mathrm{ha}^{-1}$ in $\mathrm{T}_{1}$, $\mathrm{T}_{2}$ and $\mathrm{T}_{3}$, respectively. The highest fish production was obtained in $\mathrm{T}_{2}$ followed by $\mathrm{T}_{3}$ and the lowest in $T_{1}$. However, production of fish differed significantly $(\mathrm{P}<0.05)$ among the three treatments. 
Table 3. Growth, survival and production of shing (H. fossilis) under the three treatments

\begin{tabular}{ccccccc}
\hline Treatment & $\begin{array}{c}\text { Initial } \\
\text { weight }(\mathrm{g})\end{array}$ & $\begin{array}{c}\text { Harvesting } \\
\text { mean weight } \\
(\mathrm{g})\end{array}$ & $\begin{array}{c}\text { Survival } \\
(\%)\end{array}$ & FCR & $\begin{array}{c}\text { Production } \\
\left(\mathrm{kg} \mathrm{ha}^{-1}\right)\end{array}$ & SGR (\%) \\
\hline Treatment-1 & $3.26 \pm 1.11^{\mathrm{a}}$ & $69.42 \pm 6.20^{\mathrm{a}}$ & $87 \pm 3.6^{\mathrm{a}}$ & 2.78 & $7,549 \pm 52^{\mathrm{b}}$ & $2.33^{\mathrm{a}}$ \\
Treatment-2 & $3.34 \pm 0.96^{\mathrm{a}}$ & $58.74 \pm 3.85^{\mathrm{b}}$ & $82 \pm 4.58^{\mathrm{a}}$ & 3.12 & $9,031 \pm 71^{\mathrm{a}}$ & $2.22^{\mathrm{a}}$ \\
Treatment-3 & $3.24 \pm 1.0^{\mathrm{a}}$ & $49.50 \pm 4.52^{\mathrm{c}}$ & $71 \pm 2.64^{\mathrm{b}}$ & 3.59 & $8,786 \pm 60^{\mathrm{c}}$ & $2.13^{\mathrm{a}}$ \\
\hline
\end{tabular}

* Figures in the same column with different superscripts are significantly different $(\mathrm{P}>0.05)$

Correlation matrix among stocking density, density increased, then mean values of harvesting weight, survival, FCR, SGR (\%) and harvesting weight, survival and SGR decreased. production of shing is shown in Table 3 and gave While, harvesting weight showed positive a clear picture of the relationships among the correlation with survival but negative correlation parameters (Table 4). Stocking density showed a with FCR and production. Survival rate indicated negative correlation with harvesting weight, the negative correlation with FCR and survival and SGR. It means that if stocking production.

Table 4. Correlation matrix among stocking density, harvesting weight, survival, FCR, SGR and production of shing under grow-out system

\begin{tabular}{lcccccc}
\hline Parameter & $\begin{array}{c}\text { Stocking } \\
\text { density }\end{array}$ & $\begin{array}{c}\text { Harvesting } \\
\text { Wt. (g) }\end{array}$ & Survival (\%) & FCR & SGR & $\begin{array}{c}\text { Production } \\
\text { (Kg) }\end{array}$ \\
\hline Stocking density & 1.000 & - & - & - & - & - \\
Harvesting Wt. (g) & $-0.999^{*}$ & 1.000 & - & - & - & - \\
Survival (\%) & -0.978 & 0.968 & 1.000 & - & - & - \\
FCR & $0.996^{*}$ & -0.961 & $-0.993^{*}$ & 1.000 & - & - \\
SGR (\%) & $-0.998^{*}$ & 1.000 & 0.964 & $-0.989^{*}$ & 1.000 & - \\
Production (Kg ha-1) & 0.776 & -0.804 & -0.628 & 0.717 & -0.813 & 1.000 \\
\hline
\end{tabular}

* Significant difference at $5 \%$ level of probability

\section{Discussion}

Environmental parameters exert an immense influence on the maintenance of a healthy aquatic environment and production of food organisms. Growth, feed efficiency and feed consumption of fish are normally governed by a few environmental factors (Brett, 1979). The mean range of temperature $\left(27.49-27.93^{\circ} \mathrm{C}\right)$ in the experimental ponds is within the acceptable range for farming of shing that agrees well with the findings of Haque et al. (1984) and Kohinoor et al. (1994, 2007). Boyd (1982) reported that the range of water temperature from 26.06 to $31.97^{\circ} \mathrm{C}$ is suitable for fish culture. Transparency was consistently higher in all the treatments, because shing did not consume plankton in adult stage. For this reason plankton abundance was found in all the ponds of treatments. The Dissolved oxygen in the morning was low in ponds stocked with high density of fish compared to ponds stocked with a low density. Similar results were observed by Saha et al. (1988) for rohu (L. rohita) and Rahman and Rahman (2003) for calash (L. calbasu). Fluctuation of dissolved oxygen might be attributed to photosynthetic activity and variation in the rate of oxygen consumption by fish and other aquatic organisms (Boyd, 1982).
However, the level of dissolved oxygen is within the acceptable ranges in all the experiment ponds.

Roy et al. (2002) obtained a pH range 7.03 to 9.03 in fish ponds located in Trishal, Mymensingh. The observed $\mathrm{pH}$ values of water ranging from 7.3 to 9.0 indicated that the experimental ponds were suitable for fish culture (Boyd, 1982). During the study period, the $\mathrm{pH}$ values of pond water under different treatments were found to be alkaline. Roy et al. (2002) obtained a pH range 7.03 to 9.03 in fish ponds located in Trishal, Mymensingh. The observed $\mathrm{pH}$ values of water ranging from 7.1 to 8.6 indicated that the experimental ponds were suitable for fish culture (Boyd, 1982). The total alkalinity values of the pond water under different treatments were found to be productive level. Total alkalinity levels for natural waters may range from less than $5 \mathrm{mg} \mathrm{L}^{-1}$ to more than $500 \mathrm{mg} \mathrm{L}^{-1}$ (Boyd, 1982). Kohinoor et al. (1998) and Roy et al. (2002) found the average total alkalinity above $100 \mathrm{mg} \mathrm{L}^{-1}$ in their studies. Total alkalinity values found in the present study were within the suitable range (102 to 123). Total ammonia (including unionized fraction) was found in all the treatments because, high density if fish was stocked. The droppings of the fish 
might be produced more ammonia in the ponds. New (1987) reported that excessive use of feed or fertilizer caused sediments in the pond bottom which may produce ammonia in the ponds and other gases. In this experiment, this may be happened. The suitable range of Ammonia $\left(\mathrm{NH}_{3}\right)$ below $0.1 \mathrm{mg} \mathrm{L}^{-1}$ (Boyd, 1982).

Growths of fish in ponds were investigated and the results obtained from the experiment indicated that the growth rate varied in different stocking densities. Growth in terms of mean harvesting weight and SGR of $\mathrm{H}$. fossilis was significantly higher in $\mathrm{T}_{1}$ where the stocking density was low compared to the treatments of $\mathrm{T}_{2}$ and $T_{3}$ although same feed was supplied in all the treatments at an equal ratio. The low growth rate of $H$. fossilis in $T_{2}$ and $T_{3}$ appeared to be related with higher densities and increased competition for food and space and an inverse relationship with the stocking density provided that space had limiting effects operate on the population (Johnson, 1965). The present results coincide with the findings of Narejo et al. (2005) who achieved best growth at lower stocking densities in shing farming. While Mollah (1985) reported that the lower density gave higher size and higher survival rate in Clarias macrocephalus. They also reported that the lower density gave larger size and higher survival rate in $\mathrm{H}$. fossilis in cemented cistern fed on formulated feed. In the present experiment, highest harvesting mean weight and highest survival rate has been observed in lowest stocking density. The lowest stocking densities provide more space, food and less competition, which were reported by various authors like Ahmed (1982), Hasan et al. (1982) and Haque et al. (1984). The percentage of survival as recorded in the present study was 87, 82 and 81 for $T_{1}, T_{2}$ and $T_{3}$, respectively. Survival was found to be negatively influenced by stocking densities. It might be due to high competition and space among the fishes. The mean growth increase in this experiment was found to be comparable to the gain achieved in rice fields where $\mathrm{H}$. fossilis was shown to grow about $25 \mathrm{~g}$ during 60 days culture period (Dehadrai, 1981). Lipton (1983) observed that the shing attained $30.35 \mathrm{~g}$ over 112 days with gross production $1242.35 \mathrm{~g} / \mathrm{m}^{2}$ in cage culture management. In a study, Thakur and Das, (1986) reported production range was 1642 to $7,300 \mathrm{~kg} \mathrm{ha}^{-1}$ in four to eleven months culture period of $\mathrm{H}$. fossilis. In a study, Mustafa (1991) who has reported to achieve an estimated production of 1592, 2373 and $1764 \mathrm{~kg} \mathrm{ha}^{-1} \mathrm{yr}^{-1}$. from monoculture of mola (A. mola), chola punti (P. sophore) and colisha (C. fasciata), respectively. While Akhteruzzaman et al. (1991) reported that in monoculture condition the production of Puntius sarana was $1,200 \mathrm{~kg} \mathrm{ha}^{-1}$ in six months. However, Khan et al. (2003) observed the effect of different stocking densities on production of catfish ( $\mathrm{H}$. fossilis) in earthen ponds and got the production range 2080 to $3364 \mathrm{~kg} \mathrm{ha}^{-1}$. A study conducted by Kohinoor et al. (2006) obtained production of 1370 to 1535 $\mathrm{kg} \mathrm{ha}^{-1}$ in six months from Mystus cavasius in monoculture management. While in the present experiment, higher production was noticed. The reason might be due to longer culture period and higher stocking density and better management.

Therefore, the stocking density of 1,87,500 ha-1 for culture of shing, $\mathrm{H}$. fossilis is advisable for farmers in commercial basis.

\section{References}

Ahmed, G.U. 1982. Intensive culture of Labeo rohita (Hamilton) in floating ponds with special reference to different stocking. M.Sc. Thesis. Department of Fisheries Biology and Limnology. Bangladesh Agricultural University, Mymensingh. 38 p.

Akhteruzzaman, M., Kohinoor, A.H.M., Hussain, M.G. and Shah, M.S. 1991. A study on the semi-intensive culture of Puntius sarana (Hamilton). Bangladesh J. Fish. 14 (1-2): 69-72.

Anwar, M.F and Jafri, A.K. 1995. Effects of varying dietary lipid levels on growth, feed conversion, nutrient retention and caracass composition of fingerling catfish, Heteropneustes fossilis. Asian Fish Sci. 8: 55-62.

AOAC Assoaiation of Official Analitical Chemists, AOAC. 1984. In: Howritz, W. (Ed.), Official Methods of Analysis, 14th edn. AOAC, Washington, DC. $1018 \mathrm{p}$.

Azadi, M.A and Siddique, M.S. 1986. Fecundity of catfish, Heteropneustes fossilis (Bloch). Bangladesh J. Zool. 14: 33-39.

Boyd, C.E. 1982. Water Quality Management for Pond Fish Culture. Elsevier, The Netherlands. $318 \mathrm{p}$.

Brett, J.R. 1979. Environmental factors and growth. In: Hoar, W.S., Randal, D.J. Brett, J.R. (Eds.) Environmental relations and behavior, Fish Physiology, vol. 6. Academic press, New York. pp. 599-677.

Dehadrai, P.V. 1981. Integration of air breathing cat fish culture with livestock and crop agriculture, In: Summer Institute of Farming System Integrating agriculture and livestock. 8 p.

Dehadrai, P.V., Yusuf, K.M. and Das, R.K. 1985. Package and practices for increasing production of air breathing fishes. In: Aquaculture Extension Manual, New Series, Information and Extension Division of CIFRI. Indian Council of Agriculture Research. pp. 1-14. 
Hasan, M.R., Aminul Haque, A.K.M., Islam, M.A and Khan, E.U.K. 1982. Studies on the effect of stocking density on the growth Nile tilapia, Saratherodon nilotica (Linnaeus) in floating ponds. Bangladesh. J. Fish. 2 (5): 73-81.

Haque, M.M., Alam, A.K.M.N. and Islam, M.A. 1988. Culture prospects of shying (Heteropneustes fossilis) in floating cages. Bangladesh J. Fish. 12: 67-72.

Haque, M.M., Islam, M.A., Ahmed, G.U. and Haq, M.S. 1984. Intensive culture of Java Tilapia (Oreochromis mossambicus) in floating ponds at different stocking densities. Bangladesh J. Fish. 7 (1-2): 55-59.

Hossain, M.A., Islam, M.N. and Ali, M.A. 1993. Evaluation of silkworm pupae meal as a dietary protein source of catfish (Heteropneustes fossilis). In: S.J. Kaaushih and P. Luguent Heteropneustes fossilis (Editors). Fish Nutrition in Practice. Biarritz, France. pp. 785-791.

Hussain, M.G. and Mazid, M.A. 2001. Genetics Improvement and Conservation of Carp Species in Bangladesh. Bangladesh Fisheries Research Institute, Mymensingh. 56 p.

IUCN, Bangladesh. 2000. Red book of threatened fish of Bangladesh. The world Conservation Union. Appendix 1, $61 \mathrm{p}$.

Johnson, W.E. 1965. On mechanism of self regulation of population abundance in Oncorhynchus nerka. Mitt. Int. Verein. Theor. Angew. 13: 66-87.

Khan, M.N., Saiful Islam, A.K.M. and Hussain, M.G. 2003. Marginal analysis of culture of stinging catfish (Heteropneustes fossilis): Effect of different stocking density in earthen ponds. Pakistan J . Biol. Sci. 6 (7): 666-670.

Kohinoor, A.H.M., Haque, M.Z., Hussain, M.G. and Gupta, M.V. 1994. Growth and survival of Thi punti, Puntius gonionotus (Bleeker) spawn in nursery ponds at different stocking densities. J. Asia. Soc. Bangladesh Sci. 20 (1): 65-72.

Kohinoor, A.H.M, Islam, A.K.M.S., Jahan, D.A., Zaher, M. and Hussain, M.G. 2007. Monoculture of climbing perch, Thai koi, Anabas testudineus (Bloch) under different stocking densities at on-farm management. Bangladesh J . Fish. Res. 11(2): 173-180.

Kohinoor, A.H.M., Islam, M.L., Wahab, M.A. and Thilsted, S.H. 1998. Effect of mola (Amblypharyngodon mola, Hamilton) on the growth and production of carps in polyculture. Bangladesh J. Fish. 2 (2): 119126.

Kohinoor, A.H.M., Momtaz Begum and Hussain, M.G. 2006. Culture potentials of gulsha (Mustus cavasius) in monoculture management under different stocking densities. Bangladesh J. Fish. Res. 8 (2): 95100.
Kuddus, R., Kuddus, M.M.A. and Shafi, M. 1995. Feeding and breeding habits of shing fish, Heteropneustes fossilis (Bloch). Dhaka Univ. J . Biol. Sci. 5: 35-43.

Lipton, A.P. 1983. Studies on the culture of Heteropneustes fossilis in cages. Proc. Natl. Sem. Cage Culture. pp. 51-54.

Mollah, M.F.A. 1985. Effects of stocking density and water depth on the growth and survival of freshwater catfish (Clarias macrocephalus) larvae. Indian J . fish. 32: 117.

Mustafa, G. 1991. Composite culture and biology of some indigenous fishes of Bangladesh. Ph. D. Thesis. Faculty of Biological Science, Dhaka University. 299 p.

Narejo, N.T., Salam, M.A., Sabur, M.A. and Rahmatullah, S.M. 2005. Effect of stocking density on growth and survival of indigenous catfish, Heteropneustes fossilis (Bloch) reared in cemented cistern fed on formulated feed. Pakistan J. Zool. 37 (1): 49-52.

New, M.B. 1987. Food and feeding of fish and shrimp. Ext. Man. Aqua. Dev. Coor. Prog. ADCP/ REP/ 87/26. FAO and UNEP. 275 p.

Rahman, M.A., Gheyasuddin, H., Rasid, M.H. and Choudhury, M.F.Z. 1982. Proximate composition and native quality of freshwater Zeol fishes of Bangladesh. Bangladesh J. Fish. 2-5: 34-43.

Rahman, M.R and Rahman, M.A. 2003. Studies on the growth, survival and production of calbasu (Labeo calbasu, Ham.) at different stocking densities in primary nursing. Bull. Fac. Sci., Unv. Ryuyus, J pn. 76: 245-255.

Roy, N. C., Kohinoor, A.H.M., Wahab, M.A. and Thilsted, S.H. 2002. Evaluation of performance of Carp-SIS Polyculture technology in the rural farmer's pond. Asian Fish. Sci. 15: 41-50.

Saha, J.K. 1998. Studies on the induced breeding and post larval rearing of shing, Heteropneustes fossillis (Bloch). Bangladesh J. Fish. Res. 2: 10-15.

Saha, S.B., Gupta, M.V., Hussain, M.G. and Shah, M.S. 1988. Growth and survival of rohu (Labeo rohita ham.) fry in rearing ponds at different stocking densities. Bangladesh J. Zool. 16: 119-126.

Thakur, N.K and Das, P. 1986. Synopsis of biological data on Koi, Anabas testudineus (Bloch). Heteropneustes fossilis Bulletin No. 40, Central Inland Fisheries research Institute, Barrackpore, India. 47p.

Thakur, N.K, Naser, S.A.K. and Shell, M. 1977. Spawning behaviour of an air breathing cat fish, Heteropneustes fossilis (Bloch). Physiol. Behav. 19: 53-55. 